\title{
Adsorption of Lead(II) Ions using Coconut Fiber's (Cocos nusifera L.) Activated by Sodium Hydroxide
}

\section{*Gatut Ari Wardani, Dea Dara Pamungkas, Winda Trisna Wulandari, Fajar Setiawan \& Estin Nofiyanti}

Farmasi - STIKes Bakti Tunas Husada Tasikmalaya, Tasikmalaya - Indonesia 46115

Farmasi - STIKes Bakti Tunas Husada Tasikmalaya, Tasikmalaya - Indonesia 46115

Farmasi - STIKes Bakti Tunas Husada Tasikmalaya, Tasikmalaya - Indonesia 46115

Farmasi - STIKes Bakti Tunas Husada Tasikmalaya, Tasikmalaya - Indonesia 46115

Teknik Lingkungan - Universitas Muhammadyah Tasikmalaya, Tasikmalaya - Indonesia 46196

Received 18 March 2020, Revised 21 April 2020, Accepted 22 May 2020

doi: 10.22487/j24775185.2020.v9.i2.pp107-110

\section{Abstract}

The use of green coconut fiber waste to adsorb lead(II) ions has been successfully carried out. Coconut fiber is activated first using sodium hydroxide before being used as an adsorbent. The optimum time needed for green coconut fiber to adsorb lead(II) ions was 30 minutes with the percentage of ions adsorbed by $94.34 \%$. The lead(II) adsorption kinetics on green coconut fiber model with $R^{2}$ value of 0.999 and $k$ value of $38.95 \times 10^{-4}$ minutes $^{-1}$. Adsorption isotherm from lead(II) on coconut fiber followed the Langmuir adsorption model with $R^{2}$ value of 0.984 and adsorption capacity of $0.070 \mathrm{~g}^{\mathrm{mg} \mathrm{g}^{-1}}$.

Keywords: Green coconut fiber, biosorbent, lead, sodium hydroxide

\section{Pendahuluan}

Kelangsungan hidup bagi makhluk hidup seperti manusia sangat bergantung dengan ketersediaan air bersih. Namun, saat ini ketersediaan air bersih sangat sulit untuk diperoleh karena terjadinya pencemaran air. Air buangan (limbah rumah tangga atau limbah industri) merupakan salah satu faktor penyebab terjadinya pencemaran. Logam berat diketahui sebagai salah satu bahan yang berpotensi sebagai pencemar lingkungan perairan.

Logam berat yang terdapat di dalam lingkungan perairan akan mengancam kelangsungan hidup makhluk hidup. Logam berat yang dapat menimbulkan pencemaran air salah satunya adalah timbal. Industri baterai, bahan bakar, pengecoran ataupun pemurnian dan industri kimia lainnya dapat menjadi jalannya logam timbal masuk ke perairan (Safrianti, dkk., 2012; Diantariani, 2010; Kurniasari, dkk., 2012).

Menurut Ashraf, dkk. (2010), proses pemisahan ion logam biasanya memerlukan biaya yang besar dan efektivitasnya juga rendah jika diaplikasikan pada konsentrasi yang rendah. Maka dari itu, saat ini dibutuhkan alternatif pengolahan limbah logam berat yang efektif, efisien dan murah (Sudiarta \& Dwi, 2010). Salah satu metode yang dapat digunakan untuk mengatasi masalah tersebut adalah biosorpsi karena memanfaatkan bahan-bahan biomaterial yang mudah didapat dan biayanya relatif murah (Alluri, dkk., 2007).

Biosorpsi mempunyai kemampuan menyerap logam berat dari dalam larutan melalui langkah-langkah metabolisme atau kimia fisika. Proses ini tidak memerlukan proses pemindahan limbah karena dapat dilakukan ditempat. Bahan baku yang melimpah, murah, proses pengolahan limbah yang efisien, minimalisasi lumpur yang tersebut, serta tidak adanya nutrisi serta proses regenerasi merupakan keuntungan lain dalam pemakaian biosorben (Ashraf, dkk, 2010).

Pinandari, dkk. (2011); Tyas, (2000) mengemukakan bahwa sabut kelapa (Cocos nucifera L.) dapat dimanfaatkan sebagai salah satu bahan biomaterial yang dapat menyerap logam. Limbah sabut kelapa dapat digunakan sebagai bahan yang mampu mengurangi kadar logam tembaga $(\mathrm{Cu})$ dan besi $(\mathrm{Fe})$ (Mastiani, dkk., 2018). Dengan demikian, limbah sabut kelapa diharapkan mampu dimanfaatkan sebagai biosorben untuk mengurangi kandungan ion logam timbal(II) dalam perairan (Wardani,2018; Sudiarta \& Emmy, 2011). Penelitian ini mengkaji kinetika dan isoterm adsorpsi logam timbal(II) pada limbah sabut kelapa yang teraktivasi teraktivasi oleh natrium hidroksida.

Artikel ini mendeskripsikan pemanfaatan limbah sabut kelapa teraktivasi untuk digunakan

${ }^{*}$ Correspondence:

Gatut Ari Wardani

e-mail: gatutariwardani@stikes-bth.ac.id

(c) 2020 the Author(s) retain the copyright of this article. This article is published under the terms of the Creative Commons Attribution License 4.0, which permits unrestricted non-commercial use, distribution, and reproduction in any medium, provided the original work is properly cited. 
sebagai absorben ion logam berat timbal(II) dalam perairan.

\section{Metode}

\section{Alat dan Bahan}

Bahan-bahan yang digunakan dalam penelitian ini adalah limbah sabut kelapa, natrium hidroksida $(\mathrm{NaOH})$, timbal nitrat $\left(\mathrm{Pb}\left(\mathrm{NO}_{3}\right)_{2}\right)$, dan aquades. Peralatan yang digunakan antara lain peralatan gelas laboratorium, neraca analitik (Ands GR-200), ayakan, spektrometer serapan atom (SSA, ContrAA 300), dan spektrometer FTIR (Simadzu).

\section{Aktivasi Limbah Sabut Kelapa}

Sabut kelapa hijau dibersihkan dari kotoran-kotoran yang menempel. Kemudian dicuci menggunakan aquades hingga bersih. Sabut kelapa hijau yang sudah bersih dikeringkan dibawah sinar matahari sampai kering. Sabut kelapa hijau yang telah kering dihaluskan dan diayak menggunakan ayakan dengan mesh 60 . Serbuk sabut kelapa hijau kemudian disimpan dalam botol kedap udara, dan dilakukan analisis gugus fungsi dengan cara mengambil 0.125 gram serbuk sabut kelapa hijau. Serbuk sabut kelapa hijau yang telah dihaluskan, ditambahkan $\mathrm{NaOH}$ 5\%. Campuran kemudian diaduk selama 30 menit. Setelah itu, serbuk sabut kelapa hijau disaring dan dicuci dengan menggunakan aquades sampai memperoleh padatan netral kemudian di oven pada suhu $80^{\circ} \mathrm{C}$ sampai mendapatkan bobot konstan.

\section{Studi Kinetika Adsorpsi}

0.125 gram serbuk sabut kelapa hijau direndam dengan $25 \mathrm{~mL}$ larutan Timbal(II) 10 ppm. Waktu interaksi rendaman divariasikan selama $0,15,30$, dan 45 menit. $10 \mathrm{~mL}$ filtrat diambil dan kemudian dianalisis menggunakan spektrofotometer serapan atom (SSA) untuk mengetahui jumlah ion Timbal(II) yang tersisa dalam larutan.

\section{Studi Isoterm Adsorpsi}

0.125 gram serbuk sabut kelapa hijau direndam dengan $25 \mathrm{~mL}$ larutan $\mathrm{Pb}$. Konsentrasi Timbal(II) divariasikan sebesar 5, 10, 15, 20 dan $25 \mathrm{ppm}$. Campuran kemudian diaduk selama 30 menit. $10 \mathrm{~mL}$ filtrat diambil dan kemudian dianalisa menggunakan spektrofotometer serapan atom (SSA) untuk mengetahui Timbal(II) yang tersisa dalam larutan.

\section{Hasil dan Pembahasan}

\section{Studi Kinetika Adsorpsi}

Waktu terbaik biosorben dalam menyerap ion logam yaitu setelah menit ke-30 dan konsentrasi terbaik sebanyak 5 ppm dengan kadar ion timbal yang teradsorpsi sebesar $94.34 \%$.

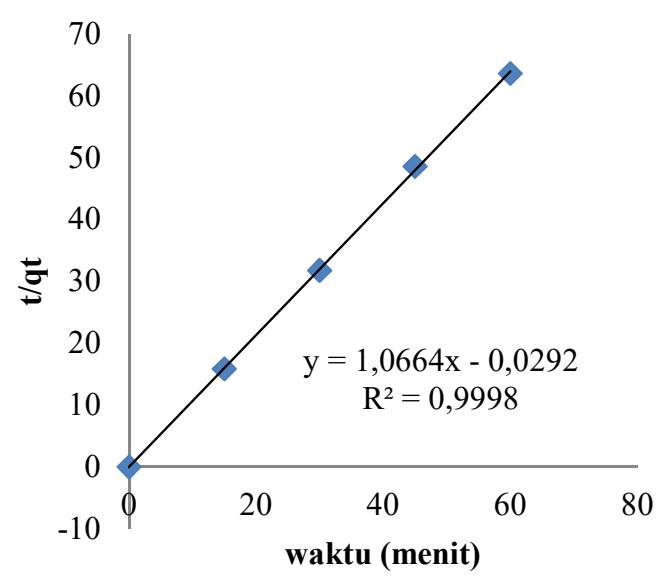

Gambar 1. Pola studi kinetika model Ho.

Model kinetika adsorpsi dari sabut kelapa hijau yang telah diaktivasi mengacu pada model kinetika Ho (Gambar 1) dan didapat nilai $\mathrm{R}^{2}$ sebesar 0.9998 dan konstan laju $(k)$ sebesar 38.95 x $10^{-4}$ menit $^{-1}$. Semakin lama waktu interaksi yang dibutuhkan pada saat proses penyerapan berbanding lurus dengan berkurangnya jumlah ion Timbal(II) yang tersisa didalam larutan residu. Penyerapan adsorbat oleh adsorben dipengaruhi oleh konsentrasi adsorbat dan situs aktif biosorben (Yanti, dkk., 2016. Muslich \& Hayuningtyas, 2010). Hal ini sesuai bahwa model kinetika Ho didasarkan pada konsentrasi adsorbat pada adsorben, model kinetika Ho disebut dengan pseudo orde dua (Utomo, dkk., 2009).

\section{Studi Isoterm Adsorpsi}

Hubungan antara jumlah Timbal(II) yang teradsorpsi pada sabut kelapa hijau dengan konsentrasi Timbal(II) dalam fase cair pada temperatur tertentu disebut dengan adsorpsi isoterm (Wardani, dkk., 2017). Berdasarkan Gambar 2, dapat disimpulkan bahwa isotherm adsorpsi mengikuti model isoterm langmuir sebagai acuan karena nilai $\mathrm{R}^{2}$ (regresi linier) nya mendekati angka 1 yaitu sebesar 0.984 . Dari hasil linieritas pada model kinetika adsorpsi sabut 
kelapa hijau menggunakan kurva langmuir dihasilkan nilai $\mathrm{R}^{2}$ sebesar 0.984 dan kapasitas adsorpsi (b) adalah 0.070 g.mg ${ }^{-1}$ dengan waktu terbaik adalah menit ke 45 serta konsentrasi terbaik 25 ppm.

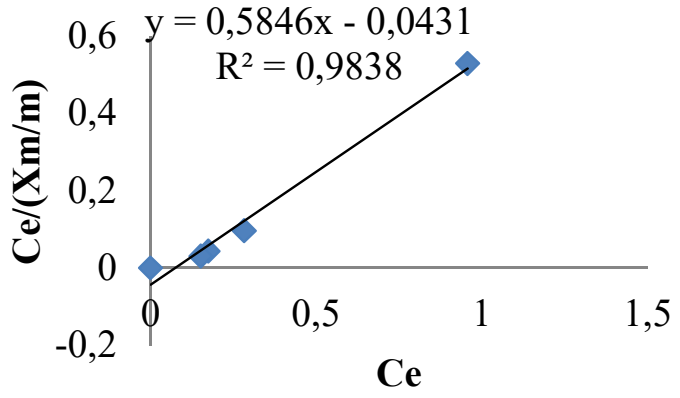

(a)

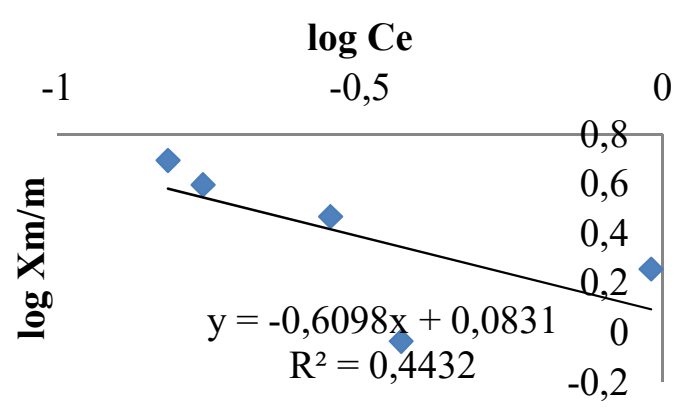

(b)

Gambar 2. Isoterm adsorpsi (a) model Langmuir dan (b) model Freundlich

Berdasarkan model isoterm Langmuir maka dapat dikatakan bahwa biosorben sabut kelapa hijau bersifat homogen sehingga menyebabkan adsorpsi ion logam timbal pada permukaan biosorben hanya membentuk satu lapisan (monolayer) adsorbat pada permukaan situs aktif biosorben, hal ini terjadi karena situssitus aktif yang ada pada biosorben memiliki energi adsorpsi yang sama terhadap adsorbat sehingga hanya akan mampu membentuk lapisan monolayer adsorbat.

\section{Kesimpulan}

Limbah sabut kelapa hijau dapat dimodifikasi menjadi biosorben ion logam Timbal(II). Model kinetika adsorpsi dari sabut kelapa hijau yang telah diaktivasi mengacu pada model kinetika Ho dengan nilai $\mathrm{R}^{2}$ sebesar 0.999 dan biosorben mampu menyerap sebesar 34.25 mg adsorbat dalam 30 menit. Kurva adsorpsi isoterm langmuir sebagai acuan dengan nilai $\mathrm{R}^{2}$ mendekati angka 1 sebesar 0.984 dan kapasitas adsorpsi (b) sebesar 0.070 g.mg ${ }^{-1}$. menit $^{-1}$ dengan waktu terbaik adalah menit ke 45 serta konsentrasi terbaik 25 ppm.

\section{Ucapan Terima Kasih}

Ucapan terima kasih disampaikan secara khusus kepada DRPM Kemenristekdikti yang telah mendanai penelitian ini melalui program hibah Penelitian Dosen Pemula tahun 2018.

\section{Referensi}

Alluri, H. K., Ronda, S. R., Sttaluri, V. S., Singh, B. J. S., Suryanarayan, V., \& Venkateshwar, P. (2007). Biosorption: an eco-friendly alternative for heavy metal removal. African Journal of Biotechnol, 6(25), 2924-2931.

Ashraf, M. A., Maah, M. J., \& Yusoff, I. (2010). Study of banana peel (musa sapientum) as a cationic biosorben. American-Eurasian Journal of Agricultural \& Environmental Sciences, 8(1), 7-17.
Diantariani, N. P. (2010). Peningkatan potensi batu padas ladgestone sebagai adsorben ion logam berat $\mathrm{Cr}$ (III) dalam air melalui aktivasi asam dan basa. Jurnal Kimia, 4(1), 91-100.

Kurniasari, L., Riwayati, I., \& Suwardiyono. (2012). Pektin sebagai alternatif bahan baku biosorben logam berat. Momentum, 8(1), 1-5.

Mastiani, N., Vina, A., \& Tina, D. R. (2018). Potensi penggunaan tempurung kelapa sebagai adsorben ion logam Fe(III). AlKimiya, 5(1), 42-47.

Muslich, S. P., \& Hayuningtyas, I. (2010). Studi kinetika adsorpsi $\beta$-karoten dari minyak kelapa sawit mentah menggunakan bentonit. Jurnal Teknik Industri Pertanian, 19(2), 93100.

Pinandari, A. W., Fitriana, D. N., Nugraha, A., \& Suhartono, E. (2011). Uji efektifitas dan efisiensi filter biomassa menggunakan sabut kelapa (cocos nucifera) sebagai bioremoval untuk menurunkan kadar logam $(\mathrm{Cd}, \mathrm{Fe}, \mathrm{Cu})$ total padatan tersuspensi (TSS) dan meningkatkan $\mathrm{pH}$ pada limbah air asam tambang batubara. Prestasi, 1(1), 1-12.

Safrianti, I., Wahyuni, N., \& Zaharah, T. A. (2012). Adsorpsi timbal(II) oleh selulosa limbah jerami padi teraktivasi asam nitrat : pengaruh pH dan waktu kontak. Jurnal Kimia Khatulistiwa, 1(1), 1-7.

Sudiarta, I. W., \& Dwi, A. Y. (2010). Biosorbsi kromium(VI) pada serat sabut kelapa hijau (cocos nucifera). Jurnal Kimia, 4(2), 158-166.

Sudiarta, I. W., \& Emmy, S. (2011). Biosorpsi Cr(III) pada biosorben serat sabut kelapa teraktivasi natrium hidroksida $(\mathrm{NaOH})$. Jurnal Kimia, 5(2), 133-142.

Tyas, S. I. (2000). Studi netralisasi limbah serbuk sabut kelapa (cocopeat) sebagai media tanam. Skripsi Tidak Diterbitkan. Bogor: Institut Pertanian Bogor. 
Utomo, S. B., Jumina, \& Taufik, D. W. (2009). Adsorpsi $\mathrm{Pb}(\mathrm{II})$ dan $\mathrm{Cr}(\mathrm{III})$ oleh polimer polipropilkaliks[4]arena. Indonesian Journal of Chemical Science, 9(3), 437-444.

Wardani, G. A., \& Winda. T. W. (2017). Studi kinetika dan isoterm adsorpsi timbal(II) pada kulit jengkol (pithecellobium jiringa) teraktivasi. Kovalen: Jurnal Riset Kimia, 3(3), 252-257.

Wardani, G. A., Dea, D. P., Winda T. W., \& Fajar, S. (2018). Pengaruh waktu kontak dan keasaman terhadap daya 83 bio adsorpsi limbah sabut kelapa hijau pada ion logam timbal(II). Kovalen: Jurnal Riset Kimia, 4(2), 215-220.

Yanti, I., Santosa, S. J., \& Kartini, I. (2016). Kinetics study of $\mathrm{Au}(\mathrm{III})$ adsorption on gallic acid intercalated mg/Al-hydrotalcite. Eksakta: Jurnal of Science and Data Analysis, 16(2), 27-35. 